\title{
Khat promotes human breast cancer MDA-MB-231 cell apoptosis via mitochondria and MAPK-associated pathways
}

\author{
YU LU ${ }^{1}$, YANYAN LI ${ }^{2}$, MIN XIANG ${ }^{3}$, JIE ZHOU $^{3}$ and JUAN CHEN ${ }^{3}$ \\ ${ }^{1}$ Department of Endocrinology, Taizhou People's Hospital, Nantong University, Taizhou, Jiangsu 225300; \\ ${ }^{2}$ Department of Neurosurgery and Brain and Nerve Research Laboratory, The First Affiliated Hospital of Soochow University, \\ Suzhou, Jiangsu 215006; ${ }^{3}$ Department of Biochemistry and Molecular Biology, Tongji Medical College, \\ Huazhong University of Science and Technology, Wuhan, Hubei 430030, P.R. China
}

Received October 10, 2015; Accepted March 23, 2017

DOI: $10.3892 / 01.2017 .6708$

\begin{abstract}
Khat (Catha edulis Forsk) is a flowering evergreen plant in Eastern Africa and Southwestern Arabia. Consumption of Khat has been associated with the development of oral cancer, but its mechanism of action on the molecular level remains unclear. The present study demonstrated the cytotoxic effect of khat extracts on the human breast cancer cell line MDA-MB-231. Trypan blue exclusion assays, flow cytometry, fluorescent and electron microscopy, as well as western blotting were used to analyze the effects of Khat on the cell viability of breast cancer cells, expression of apoptotic-associated proteins and the levels of reactive oxygen species (ROS). The results of the present study demonstrated that treatment with $400 \mu \mathrm{g} / \mathrm{ml}$ khat was able to induce cell death in breast cancers, with an increase in the protein expression of apoptosis regulator Bax and a decrease in the expression of B-cell lymphoma 2, along with a decrease in ROS levels in a time-dependent manner. Furthermore, the expression of activated c-Jun N-terminal and extracellular regulated protein kinases was increased in khat-treated cells compared with untreated cells. Mitochondria participated in cell apoptosis through the release of apoptogenic proteins to the cytosol and the generation of excess reactive oxygen species. The results of the present study suggest that khat induces MDA-MB-231 cell apoptosis via MAPK activation and mitochondrial-mediated death.
\end{abstract}

\section{Introduction}

Khat is an herb that is used by millions of people worldwide for its psychostimulatory effects, primarily in Africa and the

Correspondence to: $\mathrm{Dr} \mathrm{Yu} \mathrm{Lu}$, Department of Endocrinology, Taizhou People's Hospital, Nantong University, 210 Yingchun Road, Taizhou, Jiangsu 225300, P.R. China

E-mail: luyu_666@126.com

Key words: khat, MDA-MB-231 cells, apoptosis, mitogen-activated protein kinase, mitochondrial-mediated death
Middle East. The alkaloid in khat is the major ingredient that can be efficiently extracted and absorbed orally (1). Khat contains numerous pharmacologically active compounds (2). Cathinone is a major alkaloid compound in fresh khat leaves, which is relatively unstable and rapidly metabolized into cathine (norpseudoephedrine) and norephedrine (1). Furthermore, other alkaloids, including phenylpentenylamines and cathedulines may exert pharmacological effects $(3,4)$. The majority of their pharmacological effects have been suggested to be mediated by releasing biogenic amines through preferential binding with the norepinephrine receptor, partially through binding with dopamine and 5-hydroxytryptamine receptors (5).

Khat chewing has been reported to impact the sexual behavior of males and females. Studies have shown that khat possesses aphrodisiac activities (6-8) and may be used to cure premature ejaculation (9). In addition, khat has been reported to be a psychostimulant (10). Medicinal uses of Khat for the treatment of depression, hunger, fatigue, obesity and gastric ulcers have also been previously reported (11). Khat can affect the cardiovascular, digestive, endocrine, hepatobiliary, respiratory and genitourinary systems (12). Previous studies have indicated that khat is associated with oral cancer development (13) and hepatic cell apoptosis (14). To the best of our knowledge, no studies have investigated the effects of khat consumption on breast cancer.

Programmed cell death may occur via apoptosis, necrosis or excessive autophagy, of which, mitochondria serve an essential role in its regulation $(15,16)$. The B-cell lymphoma 2 (Bcl-2) family is involved in mitochondria-mediated cell death by affecting the stability of the outer mitochondrial membrane (17). Anti-apoptotic Bcl-2 and Bax have been demonstrated to be associated with spontaneous apoptosis in acute myeloid leukemia cells in vitro (18). A previous study has suggested the use of the Bax to Bcl-2 ratio in patient cells to predict clinical response and outcome (19). Mitochondria participate in cell death mechanisms through the release of apoptogenic proteins into the cytosol and generation of excess reactive oxidative species (ROS). The mitochondrial respiratory chain is a major source of cellular ROS and therefore, represents a target for the effects of ROS production (20). 
Khat-induced hepatocyte apoptosis is primarily regulated through the sustained activation of the c-Jun NH2-terminal kinase (JNK) signaling pathway and partially through the extracellular signal-regulated kinase (ERK) signaling cascade (14). JNK and ERK are part of the mitogen-activated protein kinase (MAPK) signaling pathways. The aim of the present study was to investigate the effects of khat on the viability and apoptosis of breast cancer cell MDA-MB-231.

\section{Materials and methods}

Khat extraction. Khat plants were purchased from a local Yemeni market, Sana'a, Yemen. Fresh khat leaves with soft stems were collected in the summer, weighed, washed three times with distilled water and dried for three days in a clean, and dry room away from sunlight. Subsequently, the leaves were weighed, packed in a tight foil packet and stored at $4^{\circ} \mathrm{C}$. Dried khat leaves (100 g) were chopped into sections $(5 \mathrm{~mm})$ and dissolved in $100 \mathrm{ml} \mathrm{95 \%} \mathrm{ethanol,} \mathrm{centrifuged} \mathrm{at} \mathrm{5,031} \mathrm{x} \mathrm{g}$ for $5 \mathrm{~min}$ at room temperature. The supernatant was filtered using filter paper. Ethanol (100 ml) was added to the remaining leaves, and the procedure was repeated. The extracted ethanol khat suspension was concentrated using a rotary evaporator (LabTech, Inc., Hopkinton, MA, USA) at $30^{\circ} \mathrm{C}$ at a speed of $0.44 \mathrm{x}$ g until $70 \%$ of the ethanol solvent had evaporated. The viscous solution was diluted with $100 \mathrm{ml}$ distilled water and stirred at $201 \mathrm{x} \mathrm{g}$ for $60 \mathrm{~min}$ at room temperature. The filtered liquid was stored at $-70^{\circ} \mathrm{C}$ for $24 \mathrm{~h}$ and subsequently dried using a lyophilization apparatus (Lyophilization Technology, Inc., Warminster, PA, USA). Generally, $100 \mathrm{~g}$ dried leaves yielded $8 \mathrm{~g}$ khat extract powder. The major alkaloids in khat leaves are cathine, cathinone and norephedrine. The mean concentrations of cathinone, cathine and norephedrine in fresh khat leaves are $0.95,1.98$, and $0.54 \mathrm{mg} / \mathrm{g}$, respectively $(21-23)$. The lyophilized khat extracts were dissolved in Hank's balanced salt solution (HyClone; GE Healthcare Life Sciences, Logan, UT, USA without $\mathrm{Ca}^{2+}$ or $\mathrm{Mg}^{2+}$ to achieve a final concentration of $200 \mu \mathrm{g} / \mathrm{ml}$ and sterilized using a filter with a pore size of $0.2 \mu \mathrm{m}$.

Cell culture and treatment. MDA-MB-231 cells were cultured in Dulbecco's modified Eagle's medium (HyClone; GE Healthcare Life Sciences) with $10 \%$ fetal bovine serum (Zhejiang Tianhang Biotechnology Co., Ltd., Hangzhou, Zhejiang, China) and maintained in a humidified incubator at $37^{\circ} \mathrm{C}$ with $5 \% \mathrm{CO}_{2}$. When $60-70 \%$ confluence was achieved, the cells were treated with $400 \mu \mathrm{g} / \mathrm{ml}$ khat and left to culture for $4,8,16$, or $24 \mathrm{~h}$ at $37^{\circ} \mathrm{C}$. The cells in the control group were not treated with khat.

Analysis of cell viability. The cells were seeded into 6-well plates at $60-70 \%$ confluence, overnight at $37^{\circ} \mathrm{C}$. The cells were subsequently exposed to various concentrations of Khat (20, 200, 300 and $400 \mu \mathrm{g} / \mathrm{ml}$ ) for 4, 8, 16 and $24 \mathrm{~h}$. Cells were digested using $0.25 \%$ pancreatic enzyme liquid (without EDTA) and the resultant suspension was collected and centrifuged at $168 \mathrm{x} g$ for $5 \mathrm{~min}$ at room temperature. Then the cells were stained with $0.2 \%$ trypan blue or $5 \mathrm{~min}$ at room temperature prior to evaluation under an inverted light microscope. The cells with blue-labeled nuclei were considered dead.
Annexin V/propidium iodide (PI) staining assay. Apoptosis was assessed using an Annexin V-fluorescein isothiocyanate (FITC) apoptosis detection kit (Jiangsu KEYGEN BIOTECH Co., Ltd., Nanjing, Jiangsu, China) according to the manufacturer's protocol. Following drug treatment, cells in the 6-well plates were digested using $0.25 \%$ pancreatic enzyme liquid (without EDTA), suspension was collected and centrifuged at $168 \mathrm{x} \mathrm{g}$ for $5 \mathrm{~min}$ at room temperature, then washed with phosphate-buffered saline (PBS) twice and resuspended in $500 \mu 1$ of staining buffer with $5 \mu 1$ FITC-conjugated Annexin V and $5 \mu \mathrm{l}$ PI staining solution. The cells were incubated on ice for $30 \mathrm{~min}$ and analyzed using a FACSCalibur flow cytometer (BD Biosciences, Franklin Lakes, NJ, USA) within $1 \mathrm{~h}$. ModFit V3.2 software (BD Biosciences) was used to analyze the cell apoptosis rate. Rates of basal cell apoptosis and necrosis were determined in the untreated control group. The rates of cell apoptosis were determined following $\geq 3$ independent experiments and each experiment was performed in triplicate.

Staining of apoptotic cells with Hoechst 33258. The cells were treated with khat and fixed in $4 \%$ formaldehyde containing Hoechst $33258(10 \mu \mathrm{g} / \mathrm{ml})$. Following incubation with $400 \mu \mathrm{g} / \mathrm{ml}$ khat for different times $(0,4,8,16$ and $24 \mathrm{~h})$ at $37^{\circ} \mathrm{C}$, nuclear morphology was examined at x200 magnification with an incident light fluorescent microscope to assess apoptotic features. The apoptotic cells were determined as the fraction of intensely stained, condensed and fragmented nuclei.

Transmission electron microscopy. Cells underwent a 16-h incubation with $400 \mu \mathrm{g} / \mathrm{ml}$ khat and were observed by transmission electron microscopy. The cells were fixed in $0.1 \mathrm{M}$ sodium cacodylate buffer ( $\mathrm{pH} 7.4$ ) with $2 \%$ glutaraldehyde. The cells were rinsed with sodium cacodylate buffer and post-fixed in $1 \%$ osmium tetroxide. The cells were dehydrated with graded ethanol (50, 70 and $90 \%$ for 10 min each) and embedded in epoxy resin. The sections were double-stained with $3 \%$ uranyl acetate and lead citrate. The cells were examined under a JEOL 1230 transmission electron microscope (JEOL, Ltd., Tokyo, Japan), and micrographs were produced using an Agfa Arcus II scanner (Agfa Corporation, Shanghai, China) and Adobe Photoshop software (version 7.0.1; Adobe Systems Europe, Ltd., Maidenhead, UK).

Western blot analysis. The cells were harvested and lysed on ice for $30 \mathrm{~min}$ in radioimmunoprecipitation buffer (50 mM Tris- $\mathrm{HCl}, \mathrm{pH} 7.4,150 \mathrm{mM} \mathrm{NaCl}, 1 \%$ Nonidet P-40, $0.25 \%$ sodium deoxycholate, $50 \mathrm{mM} \mathrm{NaF}, 1 \mathrm{mM} \mathrm{Na} 3 \mathrm{VO} 4$, $5 \mathrm{mM}$ sodium pyrophosphate and a protease inhibitor tablet [Jiangsu Keygen Biotech Co., Ltd.]). The cell lysates were centrifuged at $39,514 \mathrm{xg}$ for $10 \mathrm{~min}$ at $4^{\circ} \mathrm{C}$, and the supernatants were used for western blotting. The total protein concentration was determined using the BCA Protein assay reagent (Pierce; Thermo Fisher Scientific, Inc., Waltham, MA, USA). The lysates were denatured at $100^{\circ} \mathrm{C}$ following the addition of SDS loading buffer. The proteins were separated on 4-20\% SDS-PAGE gels and subsequently transferred to nitrocellulose blotting membranes. Following blocking of the membranes with $5 \%$ non-fat dry milk in $1 \mathrm{X}$ TBST for $>1 \mathrm{~h}$ at room temperature, the membranes were incubated with 1:1,000 diluted primary 
antibodies [p-JNK (cat. no. sc-135642), JNK (cat. no. sc-1648), p-ERK (cat. no. sc-81492), ERK (cat. no. sc-271270), Bcl-2 (cat. no. sc-7382), Bax (cat. no. sc-7480) and Caspase-9 (cat. no. sc-73548); all Santa Cruz Biotechnology, Inc., Santa Cruz, California, USA] diluted in 5\% non-fat dry milk in $1 \mathrm{X}$ TBST for $>12 \mathrm{~h}$ at $4^{\circ} \mathrm{C}$. Membrane-bound primary antibodies were detected with 1:3,000 diluted secondary antibodies (affinity purified goat anti-rabbit IgG (cat. no. GB23303), goat anti-mouse IgG (cat. no. GB23301), Servicebio Biotechnology, Ltd., Wuhan, Huber, China) conjugated to horseradish peroxidase for $1 \mathrm{~h}$ at room temperature. The blots were visualized using the ECL chemiluminescence reagent kit (Servicebio Biotechnology, Ltd., Wuhan, Hubei, China), and analyzed using the ChemiDoc XRS gel imaging device (Bio-Rad Laboratories, Inc., Hercules, CA, USA).

Measurement of ROS production. The production of ROS was measured using flow cytometry with dichlorofluorescein-diacetate (DCFH-DA) as previously described (24). The cells were treated with khat $(400 \mu \mathrm{g} / \mathrm{ml})$ for $4,8,16$ and $24 \mathrm{~h}$, dissociated with trypsin-EDTA, washed twice with cold

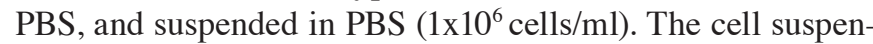
sion $(500 \mu \mathrm{l})$ was transferred into a tube and incubated with DCFH-DA at a final concentration of $5 \mu \mathrm{M}$ for $30 \mathrm{~min}$ at $37^{\circ} \mathrm{C}$. ROS production was assessed by determining the DCF fluorescence intensity from $1 \times 10^{4}$ cells by flow cytometry.

Statistical analysis. Data are presented as the mean \pm standard deviation and analyzed using the SPSS software (version 17.0; SPSS Inc., Chicago, IL, USA). One-way analysis of variance (followed by Student-Newman-Keuls post-hoc test) was used to analyze the significance of differences among groups. $\mathrm{P}<0.05$ was considered to indicate a statistically significant difference.

\section{Results}

Effect of Khat treatment on viability of MDA-MB-231 cells. The inhibitory effect of Khat was assessed by detecting the viability of MDA-MB-231 cells. As shown in Fig. 1, following Khat treatment at concentrations of 20, 200, 300 and $400 \mu \mathrm{g} / \mathrm{ml}$, the viability of MDA-MB-231 cells was inhibited in a dose- and time-dependent manner, with the greatest effect seen at the concentration of $400 \mu \mathrm{g} / \mathrm{ml}$ following a treatment duration of $8 \mathrm{~h}$. Therefore, a concentration of $400 \mu \mathrm{g} / \mathrm{ml}$ Khat was selected for use in subsequent experiments.

Effect of khat treatment on apoptosis of MDA-MB-231 cells. To investigate the effect of $400 \mu \mathrm{g} / \mathrm{ml}$ khat on apoptosis of MDA-MB-231 cells, the cells were double-stained with Annexin $\mathrm{V}$ and PI, prior to detection using flow cytometry. Following serum-free culture for $24 \mathrm{~h}$, MDA-MB-231 cells were exposed to $400 \mu \mathrm{g} / \mathrm{ml}$ khat for $4,8,16$ and $24 \mathrm{~h}$ prior to the apoptosis assay. As shown in Fig. 2, the apoptotic rates of the control, and cells exposed to khat for $4,8,16$ and $24 \mathrm{~h}$ were $7.76 \pm 2.86,9.7 \pm 1.59,10.58 \pm 2.03,13.2 \pm 4.14$, and $25.3 \pm 5.09 \%$, respectively. At each of the time point indicated, the treated cells were stained with Hoechst 33258. The nuclei of the cells in the control group were regular and round-shaped (Fig. 3A-C). By contrast, the nuclei of the majority of khat-treated $(400 \mu \mathrm{g} / \mathrm{ml} ; 16 \mathrm{~h})$ cells were condensed and fragmented, which

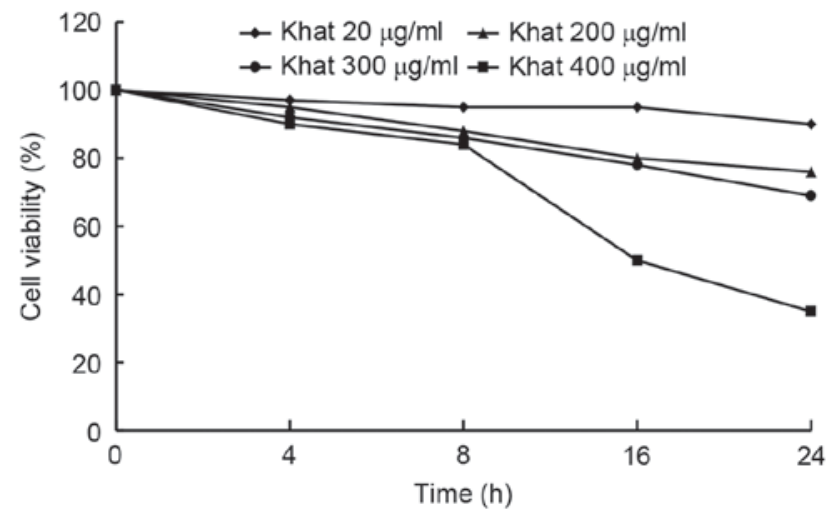

Figure 1. Effect of Khat treatment on the viability of MDA-MB-231 cells. MDA-MB-231 cells were treated with various concentrations of khat for a range of times $(0,4,8,16$ and $24 \mathrm{~h})$, Cell viability was measured using a trypan blue exclusion assay.

are characteristic of apoptotic cells (Fig. 3D and E). When observed under the electron microscope, the khat-treated cells exhibited chromatin condensation and nuclei shrinkage, which further confirms apoptosis (Fig. 3F).

Effect of Khat treatment on the expression of apoptosis-associated proteins and the activation of MAPKs. The expression of caspase-9 was determined in MDA-MB-231 cells prior to and following khat treatment using western blot analysis. The expression of caspase- 9 was not detected following Khat treatment (Fig. 4). Following incubation with $400 \mu \mathrm{g} / \mathrm{ml}$ khat for different times $(0,4,8,16$ and $24 \mathrm{~h})$, the expression of pro-apoptotic protein Bax markedly increased compared with untreated cells (i.e., cells at $0 \mathrm{~h}$ ). Conversely, the expression of anti-apoptotic protein Bcl-2 markedly decreased compared with expression levels at $0 \mathrm{~h}$.

The involvement of MAPKs in khat-induced apoptosis of MDA-MB-231 cells was subsequently investigated by measuring the expression of the activated form of JNK and ERK. As shown in Fig. 4, the size of the bands for p-JNK seem to be less intense at 16 and $24 \mathrm{~h}$ than those at 0,4 and $8 \mathrm{~h}$. The band for p-ERK at $4 \mathrm{~h}$ is higher-intesity than that at $0 \mathrm{~h}$. Similarly, the band at $24 \mathrm{~h}$ is higher intensity than that at $16 \mathrm{~h}$, while the total JNK and ERK expression were not changed. Therefore, the expression of p-JNK and p-ERK were increased when cells were treated with khat compared with untreated cells (i.e., those at $0 \mathrm{~h}$ ). It is likely that activation of ERK and JNK signal in MDA-MB-231 cells may mediate the cellular apoptotic response to khat treatment. To confirm the possible roles of JNK and ERK in khat-induced apoptosis, cell viability and apoptotic rates of MDA-MB-231 cells were determined in response to inhibitors of JNK (SP600125) and ERK (PD98059). As shown in Fig. 5, treatment with SP600125 and PD98059 significantly reversed khat-induced cell death compared with untreated cells. These results indicated that JNK and ERK are involved in khat-induced apoptosis in MDA-MB-231 cells.

Effect of khat treatment on ROS production. ROS has been considered as a potential regulator of apoptosis (25). Therefore, in the present study, the level of ROS was determined in 

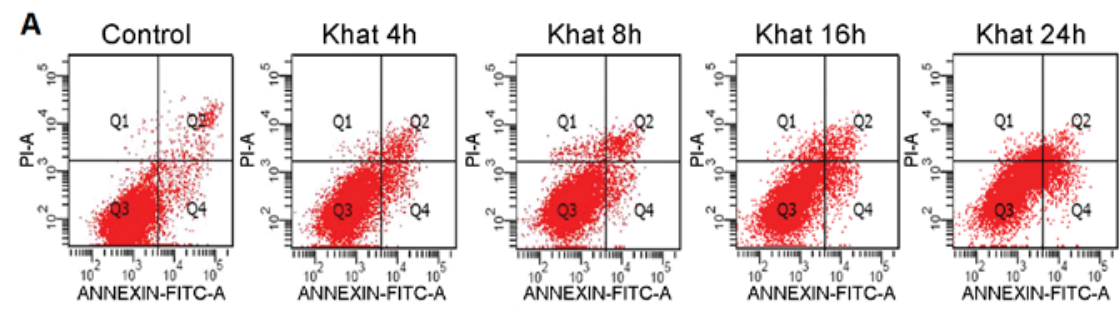

B

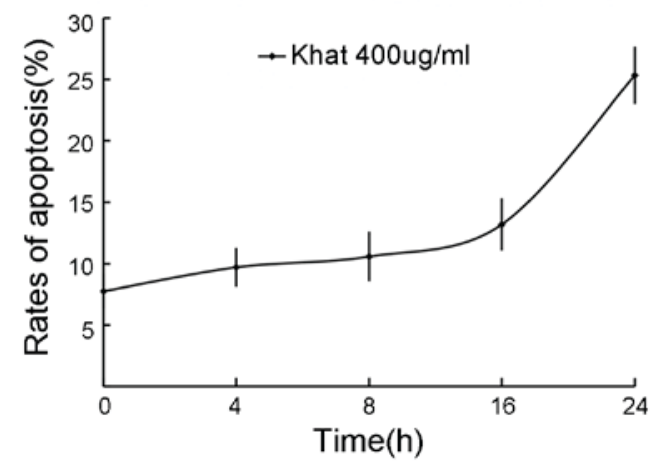

Figure 2. Analysis of apoptosis using Annexin V and PI staining. (A) MDA-MB-231 cells were double stained with Annexin V and PI, and analyzed using flow cytometry. Four populations were indicated as non-apoptosis dead cells (Q1), late apoptosis cells (Q2), viable cells (Q3) and early apoptosis cells (Q4). (B) The rate of apoptosis of cells treated with $400 \mu \mathrm{g} / \mathrm{ml}$ khat between 0 and $24 \mathrm{~h}$. PI, propidium iodide.
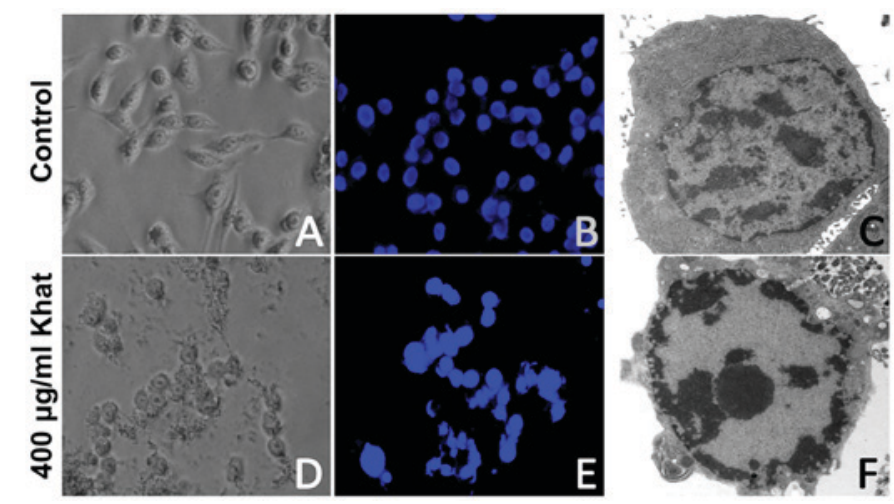

Figure 3. Morphological and ultrastructural features of untreated and khat-treated MDA-MB-231 cells for $16 \mathrm{~h}$. The untreated control cells were observed under (A) an inverted contrast light microscope (magnification, x20), (B) a fluorescence microscope following staining with Hoechst 33258 (a DNA fluorochrome) (magnification, x20) and (C) an electron microscope (magnification, x200). Khat-treated cells were observed under (D) an inverted contrast light microscope (magnification, x20), (E) a fluorescence microscope (magnification, x20) and (F) an electron microscope (magnification, x200).

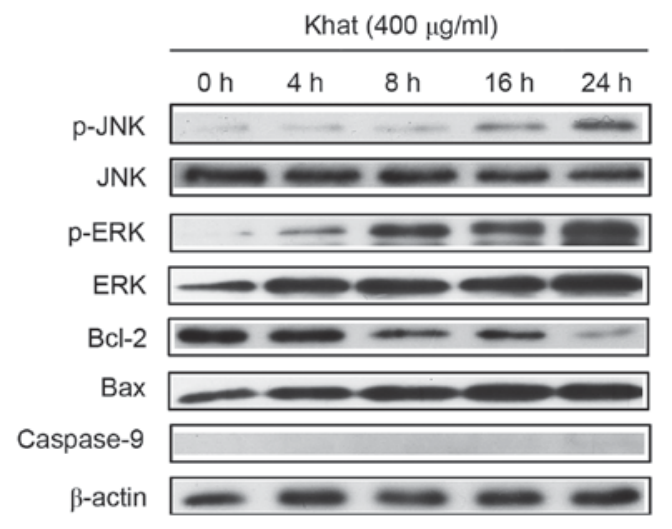

Figure 4. Expression of apoptosis-associated proteins and MAPKs (p-JNK, JNK, p-ERK, ERK). MDA-MB-231 cells were incubated with $400 \mu \mathrm{g} / \mathrm{ml}$ khat for 4, 8, 16 and $24 \mathrm{~h}$; apoptosis- and MAPK-associated protein expression was detected by western blotting. MAPK, mitogen-activated protein kinase; p, phosphorylated; ERK, extracellular signal-regulated kinase; JNK, janus kinase; Bax, apoptosis regulator Bax; Bcl-2, apoptosis regulator Bcl-2. khat-treated cells. MDA-MB-231 cells were treated with $400 \mu \mathrm{g} / \mathrm{ml}$ khat for $4,8,16$ and $24 \mathrm{~h}$ and subjected to flow cytometry for detection of ROS. As shown in Fig. 6, ROS production in cells treated with $400 \mu \mathrm{g} / \mathrm{ml}$ khat for $4 \mathrm{~h}$ was higher than control cells ( 0 h cells). Then the ROS production decreased in 8-24 h groups. khat induced a time-dependent decrease in ROS production.

\section{Discussion}

In the present study, the cell viability assay indicated that khat treatment inhibited the viability of MDA-MB-231 cells in a time- and dose-dependent manner. Flow cytometric analysis demonstrated that $400 \mu \mathrm{g} / \mathrm{ml}$ khat induced apoptosis in MDA-MB-231 cells in a time-dependent manner, which was consistent with the cell viability assay.

Apoptosis is a major mechanism of cancer suppression and is characterized by morphological and ultrastructural 
A

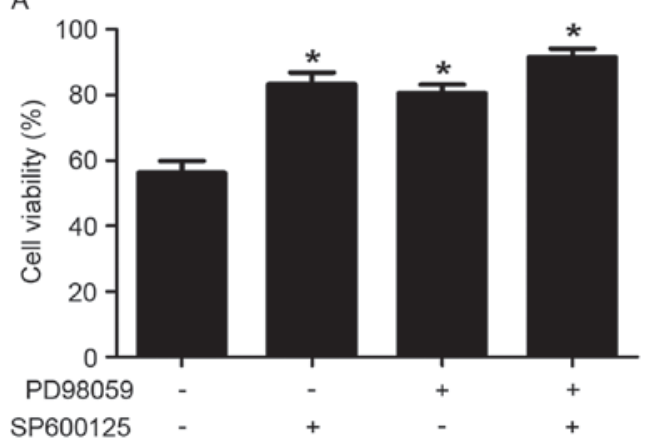

B

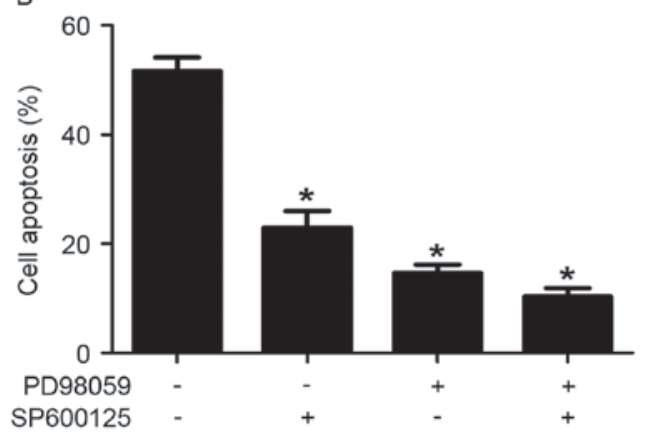

Figure 5. Inhibitors of extracellular signal-regulated kinase (PD98059) and c-Jun NH2-terminal kinase (SP600125) significantly decreased khat-induced apoptosis in MDA-MB-231 cells. (A) Cell viability was detected using a trypan blue exclusion assay (B) Cell apoptosis was analyzed using flow cytometry. ${ }^{*} \mathrm{P}<0.01$ compared with cells not treated with PD98059 and SP600125.

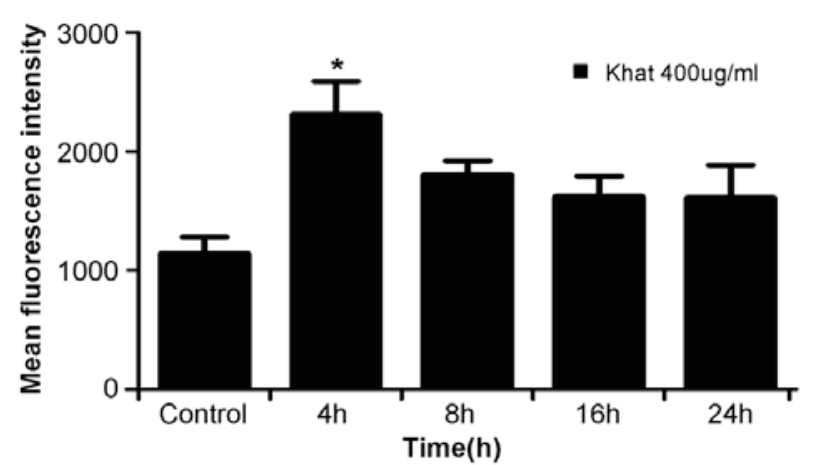

Figure 6. Effect of khat treatment on ROS production. Flow cytometry was used to assess ROS production in khat-treated $(400 \mu \mathrm{g} / \mathrm{ml})$ MDA-MB-231 cells. ROS production in cells treated with $400 \mu \mathrm{g} / \mathrm{ml}$ khat for $4 \mathrm{~h}$ was higher than control cells and then decreased in 8-24 h groups. ${ }^{*} \mathrm{P}<0.01$ compared to control cells. ROS, reactive oxygen species.

changes associated with caspase-regulated biochemical processes $(26,27)$. Khat contains a complex phytochemisty, with fractions, including flavonoids that are able to induce apoptosis and act against cancer cells (28). In the present study, Hoechst 33258 staining and transmission electron microscopy results indicated that khat induced apoptosis in MDA-MB-231 cells, and caused morphological changes, including microvilli loss, cell membrane bubbling, nuclear chromatin condensation, cytosolic compartment vacuolization and apoptotic body formation.

The MAPK signaling pathway includes the ERK, JNK and p38 pathways, which are involved in cell survival, proliferation and apoptosis. A previous study by the present authors demonstrated no significant difference in p38 expression in hepatic cells treated with khat and untreated cells (29). Therefore in the present study, the expression levels of ERK and JNK were examined in khat-treated breast cancer cells. The activation of ERK has been previously demonstrated to be involved in cell cycle progression and proliferation (30), whereas JNK is generally activated in response to stress and toxicants that induce cell apoptosis (31). Prior reports demonstrated that sustained JNK activation results in apoptosis $(32,33)$. In the present study, western blotting demonstrated that the levels of p-JNK and p-ERK were increased following treatment with khat in a time-dependent manner, whilst treatment with JNK and ERK inhibitors significantly reversed the khat-induced cell death. These results suggest that khat-induced breast cancer cell apoptosis is primarily mediated by the activation of the JNK signaling pathway.

The $\mathrm{Bcl}-2$ protein is known to be a suppressor of apoptosis (34), and Bax is a promoter of apoptosis (35). The results of the present study revealed that $\mathrm{Bcl}-2$ expression was decreased and Bax was increased in a time-dependent manner in khat-treated MDA-MB-231 cells, with an increase in $\mathrm{Bax} / \mathrm{Bcl}-2$ ratio. A previous study reported that the $\mathrm{Bax} / \mathrm{Bcl}-2$ ratio may be a more important apoptosis indicator than either promoter alone (36). The mitochondrial-mediated apoptosis signaling pathway is regulated by the Bcl-2 family of anti-apoptotic proteins (Bcl-2, Bcl-xl and myeloid cell leukemia 1) and pro-apoptotic proteins (Bax, Bcl2-associated agonist of cell death and Bcl-2 homologous antagonist/killer) (17-20). Therefore the results in the present study suggest that khat induces apoptosis in MDA-MB-231 cells via the mitochondrial-mediated apoptosis pathway. Additionally, no caspase-9 protein expression was detected in MDA-MB-231 cells, suggesting khat-induced apoptosis is not modulated by the classical apoptosis pathway.

In humans, oxidative stress has been identified to be involved in various pathologies, including cancer, arteriosclerosis, type II diabetes, ischemia/reperfusion injury, chronic inflammatory processes and various neurodegenerative diseases (37). Excess ROS can induce the oxidation of macromolecules and has been identified to be involved in ageing, mtDNA mutations and cell death (38). The generation of ROS by mitochondria serves an essential role in the release of cytochrome $\mathrm{c}$ and other pro-apoptotic proteins, which can trigger caspase activation and apoptosis (20). In the present study, ROS levels were higher in khat-treated breast cancer cells compared with that of the control cells. This result further suggests that khat-induced apoptosis is modulated by the mitochondrial-mediated apoptosis pathway.

In conclusion, the results of the present study suggest that khat causes apoptosis in MDA-MB-231 cells via sustainable activation of JNK and the mitochondrial-mediated apoptosis pathway. To the best of our knowledge, this is the first study to demonstrate that khat may suppress the breast cancer by inducing the apoptosis of breast cancer cells. 


\section{References}

1. Toennes SW, Harder S, Schramm M, Niess C and Kauert GF: Pharmacokinetics of cathinone, cathine and norephedrine after the chewing of khat leaves. Br J Clin Pharmacol 56: 125-130, 2003.

2. Kite GC, Ismail M, Simmonds MS and Houghton PJ: Use of doubly protonated molecules in the analysis of cathedulins in crude extracts of khat (Catha edulis) by liquid chromatography/serial mass spectrometry. Rapid Commun Mass Spectrom 17: 1553-1564, 2003.

3. Kalix P: Cathinone, a natural amphetamine. Pharmacol Toxicol 70: 77-86, 1992.

4. Al-Motarreb A, Baker K and Broadley KJ: Khat: Pharmacological and medical aspects and its social use in Yemen. Phytother Res 16: 403-413, 2002.

5. Rothman RB, Vu N, Partilla JS, Roth BL, Hufeisen SJ, Compton-Toth BA, Birkes J, Young R and Glennon RA: In vitro characterization of ephedrine-related stereoisomers at biogenic amine transporters and the receptorome reveals selective actions as norepinephrine transporter substrates. J Pharmacol Exp Ther 307: 138-145, 2003.

6. Bentur Y, Bloom-Krasik A and Raikhlin-Eisenkraft B: Illicit cathinone ('Hagigat') poisoning. Clin Toxicol (Phila) 46: 206-210, 2008

7. Giannini AJ, Miller NS and Turner CE: Treatment of khat addiction. J Subst Abuse Treat 9: 379-382, 1992.

8. Krikorian AD: Kat and its use: An historical perspective. J Ethnopharmacol 12: 115-178, 1984.

9. Luqman W and Danowski TS: The use of khat (Catha edulis) in Yemen. Social and medical observations. Ann Intern Med 85: 246-249, 1976

10. Feyissa AM and Kelly JP: A review of the neuropharmacological properties of khat. Prog Neuropsychopharmacol Biol Psychiatry 32: 1147-1166, 2008.

11. Safhi MM, Alam MF, Hussain S, Hakeem Siddiqui MA, Khuwaja G, Jubran Khardali IA, Al-Sanosi RM and Islam F: Cathinone, an active principle of Catha edulis, accelerates oxidative stress in the limbic area of swiss albino mice. J Ethnopharmacol 156: 102-106, 2014.

12. Kalix P and Khan I: Khat: An amphetamine-like plant material Bull World Health Organ 62: 681-686, 1984.

13. Soufi HE, Kameswaran M and Malatani T: Khat and oral cancer. J Laryngol Otol 105: 643-645, 1991.

14. Abid MD, Chen J, Xiang M, Zhou J, Chen X and Gong F: Khat (Catha edulis) generates reactive oxygen species and promotes hepatic cell apoptosis via MAPK activation. Int J Mol Med 32: 389-395, 2013.

15. Bras M, Queenan B and Susin SA: Programmed cell death via mitochondria: Different modes of dying. Biochemistry (Mosc) 70: 231-239, 2005

16. Kroemer G, Galluzzi L, Vandenabeele P, Abrams J, Alnemri ES, Baehrecke EH, Blagosklonny MV, El-Deiry WS, Golstein P, Green DR, et al: Classification of cell death: Recommendations of the nomenclature committee on cell death 2009. Cell Death Differ 16: 3-11, 2009.

17. Xiong S, Mu T, Wang G and Jiang X: Mitochondria-mediated apoptosis in mammals. Protein Cell 5: 737-749, 2014.

18. Ryningen A, Ersvaer E, Øyan AM, Kalland KH, Vintermyr OK, Gjertsen BT and Bruserud $\varnothing$ : Stress-induced in vitro apoptosis of native human acute myelogenous leukemia (AML) cells shows a wide variation between patients and is associated with low BCL-2:Bax ratio and low levels of heat shock protein 70 and 90. Leuk Res 30: 1531-1540, 2006

19. Del Poeta G, Venditti A, Del Principe MI, Maurillo L, Buccisano F, Tamburini A, Cox MC, Franchi A, Bruno A, Mazzone C, et al: Amount of spontaneous apoptosis detected by $\mathrm{Bax} / \mathrm{Bcl}-2$ ratio predicts outcome in acute myeloid leukemia (AML). Blood 101: 2125-2131, 2003.
20. Ott M, Gogvadze V, Orrenius S and Zhivotovsky B: Mitochondria, oxidative stress and cell death. Apoptosis 12: 913-922, 2007.

21. Aziz HA, Peh KK and Tan YT: Extraction and microencapsulation of khat: Effects on sexual motivation and estradiol level in female rats. J Sex Med 6: 682-695, 2009.

22. Banjaw MY and Schmidt WJ: Behavioural sensitisation following repeated intermittent oral administration of Catha edulis in rats. Behav Brain Res 156: 181-189, 2005.

23. Dimba EA, Gjertsen BT, Bredholt T, Fossan KO, Costea DE, Francis GW, Johannessen AC and Vintermyr OK: Khat (Catha edulis)-induced apoptosis is inhibited by antagonists of caspase-1 and -8 in human leukaemia cells. Br J Cancer 91: 1726-1734, 2004.

24. Su YT, Chang HL, Shyue SK and Hsu SL: Emodin induces apoptosis in human lung adenocarcinoma cells through a reactive oxygen species-dependent mitochondrial signaling pathway. Biochem Pharmacol 70: 229-241, 2005.

25. Ruan H, Zhang Z, Tian L, Wang S, Hu S and Qiao JJ: The Salmonella effector SopB prevents ROS-induced apoptosis of epithelial cells by retarding TRAF6 recruitment to mitochondria. Biochem Biophys Res Commun 478: 618-623. 2016.

26. Evan GI and Vousden KH: Proliferation, cell cycle and apoptosis in cancer. Nature 411: 342-348, 2001.

27. Hengartner MO: The biochemistry of apoptosis. Nature 407: 770-776, 2000

28. Kalix P: Pharmacological properties of the stimulant khat Pharmacol Ther 48: 397-416, 1990.

29. Abid MD, Chen J, Xiang M, Zhou J, Chen X and Gong F: Khat (Catha edulis) generates reactive oxygen species and promotes hepatic cell apoptosis via MAPK activation. Int J Mol Med 32: 389-395, 2013.

30. Mebratu Y and Tesfaigzi Y: How ERK1/2 activation controls cell proliferation and cell death: Is subcellular localization the answer? Cell cycle 8: 1168-1175, 2009.

31. Xia Z, Dickens M, Raingeaud J, Davis RJ and Greenberg ME: Opposing effects of ERK and JNK-p38 MAP kinases on apoptosis. Science 270: 1326-1331, 1995.

32. Roos WP and Kaina B: DNA damage-induced cell death by apoptosis. Trends Mol Med 12: 440-450, 2006.

33. Wullaert A, Heyninck K and Beyaert R: Mechanisms of crosstalk between TNF-induced NF-kappaB and JNK activation in hepatocytes. Biochem Pharmacol 72: 1090-1101, 2006.

34. Zhu J, Ye Q, Chang L, Xiong W, He Q and Li W: Upregulation of miR-195 enhances the radiosensitivity of breast cancer cells through the inhibition of BCL-2. Int J Clin Exp Med 8: 9142-9148, 2015.

35. Yu Y, Pei M and Li L: Baicalin induces apoptosis in hepatic cancer cells in vitro and suppresses tumor growth in vivo. Int J Clin Exp Med 8: 8958-8967, 2015.

36. Stoetzer OJ, Nüssler V, Darsow M, Gullis E, Pelka-Fleischer R, Scheel U and Wilmanns W: Association of bcl-2, bax, bcl-xL and interleukin-1 beta-converting enzyme expression with initial response to chemotherapy in acute myeloid leukemia. Leukemia 10 (Suppl 3): S18-S22, 1996.

37. Dröge W: Free radicals in the physiological control of cell function. Physiol Rev 82: 47-95, 2002.

38. Lee $\mathrm{CH}$ and Yu HS: Role of mitochondria, ROS, and DNA damage in arsenic induced carcinogenesis. Front Biosci (Schol Ed) 8: 312-320, 2016. 